\title{
Modelling overbank flood recharge at a continental scale
}

\author{
R. Doble ${ }^{1}$, R. Crosbie ${ }^{1}$, L. Peeters ${ }^{1}$, K. Joehnk ${ }^{2}$, and C. Ticehurst ${ }^{2}$ \\ ${ }^{1}$ Water for a Healthy Country, National Research Flagship, CSIRO Land and Water, PMB 2 Glen Osmond, \\ SA, 5064, Australia \\ ${ }^{2}$ Water for a Healthy Country, National Research Flagship, CSIRO Land and Water, PMB 1666 Canberra, \\ ACT, 2601, Australia
}

Correspondence to: R. Doble (rebecca.doble@csiro.au)

Received: 13 September 2013 - Published in Hydrol. Earth Syst. Sci. Discuss.: 17 October 2013

Revised: 7 February 2014 - Accepted: 13 February 2014 - Published: 3 April 2014

\begin{abstract}
Accounting for groundwater recharge from overbank flooding is required to reduce uncertainty and error in river-loss terms and groundwater sustainable-yield calculations. However, continental- and global-scale models of surface water-groundwater interactions rarely include an explicit process to account for overbank flood recharge (OFR). This paper upscales previously derived analytical equations to a continental scale using national soil atlas data and satellite imagery of flood inundation, resulting in recharge maps for seven hydrologically distinct Australian catchments. Recharge for three of the catchments was validated against independent recharge estimates from bore hydrograph responses and one catchment was additionally validated against point-scale recharge modelling and catchmentscale change in groundwater storage. Flood recharge was predicted for four of the seven catchments modelled, but there was also unexplained recharge present from the satellite's flood inundation mapping data. At a catchment scale, recharge from overbank flooding was somewhat underpredicted using the analytical equations, but there was good confidence in the spatial patterns of flood recharge produced. Due to the scale of the input data, there were no significant relationships found when compared at a point scale. Satellitederived flood inundation data and uncertainty in soil maps were the key limitations to the accuracy of the modelled recharge. Use of this method to model OFR was found to be appropriate at a catchment to continental scale, given appropriate data sources. The proportion of OFR was found to be at least $4 \%$ of total change in groundwater storage in one of the catchments for the period modelled, and at least $15 \%$ of the riparian recharge. Accounting for OFR is an important, but often overlooked, requirement for closing water balances in both the surface water and groundwater domains.
\end{abstract}

\section{Introduction}

Continental- or global-scale hydrological models provide a means for comparing the state of water storage fluxes and budgets between many hydrologically and climatically different catchments or regions (Reager and Famiglietti, 2013; Singh and Woolhiser, 2002). Contrary to comparisons between catchments with smaller-scale models, evaluations of water budgets using continental or global models may be undertaken using identical process conceptualisation and data sources.

Interactions between groundwater and surface water may be modelled either using a physically based, spatially distributed hydrological process or conceptual models. These conceptual models use a series of soil storages that interact with stream and land surface processes. Hydrological process models used to model surface water-groundwater interactions include the coupled groundwater and surface model ParFlow-CLM (Maxwell and Miller, 2005; Kollet and Maxwell, 2008) and HydroGeoSphere (Lemieux et al., 2008; Therrien et al., 2006). Conceptual models that incorporate groundwater components include PCR-GLOBWB (PCRaster Global Water Balance; Wada, 2010; Wada et al., 2012), HYPE (Hydrological Predictions for the Environment) (Lindström, 2010; Strömqvist et al., 2012) and AWRA (Australian Water Resources Assessment model) (Van Dijk and Renzullo, 2011; Van Dijk et al., 2011). Recharge to groundwater from infiltration during overbank flows has not been considered in any of the conceptual models described.

Recharge from overbank flood infiltration can be a significant, though episodic, component of a groundwater balance (Macumber, 1983; Doble et al., 2011; Jolly, 1996; Jolly et al., 1998, 1994). Distinct from bank storage, or groundwater 
recharge from losing streams, overbank flood recharge occurs when a river stage exceeds bank height and water flows in large sheets across low-lying areas. Recharge to groundwater takes place through direct vertical infiltration through the soil surface, similar to infiltration through ephemeral river beds (Dahan et al., 2008; Shentsis and Rosenthal, 2003) or recharge from disconnected streams (Brunner et al., 2009).

Infiltration through a soil from ponded surface water has been described mathematically using relationships developed in the field of irrigation science (Lewis and Milne, 1938; Philip and Farrell, 1964; Collis-George and Freebairn, 1979; Philip, 1966, 1969). These relationships have been used to model the advance of an infiltrating front for flood irrigation (Knight, 1980; Cook et al., 2013). These solutions, however, do not consider the impacts of a shallow water table, nor a dynamic water table that responds to the rise and fall of the river stage during a flood.

Doble et al. (2012) developed a simple model to calculate recharge to groundwater from overbank flooding, based on an analysis of the river-floodplain system using the fully coupled surface water-groundwater numerical flow model HydroGeoSphere (Therrien et al., 2006; Brunner and Simmons, 2011). The relationship considered the potential infiltration rate through the soil surface, the available pore space before the water table reaches the surface, and the potential for the aquifer to transport the infiltrated water away from the flooded region, which is dependent on the aquifer transmissivity.

This simple model was able to accurately represent the results for groundwater recharge predicted using the far more complex groundwater model, with a significant reduction in computational time. However, the methodology has not yet been tested at a larger scale, or against groundwater recharge estimated from field data. There is the potential to use these relationships to calculate groundwater recharge from flooding at a continental scale given an appropriate cell size.

The purpose of this paper is to apply the simple analytical overbank flood recharge (OFR) equations derived in Doble et al. (2012) to seven hydrologically different Australian catchments using continental-scale data sets and satellite imagery. The application of the method at a continental-scale is tested by comparing modelled recharge against the results from independent sources: bore estimates of groundwater recharge and catchment-scale change in groundwater storage. Pointscale infiltration modelling is used to determine the contribution of OFR to the water budget. This is done with the intention of including the OFR equations in a continental-scale water balance model.

\section{Modelling overbank flood recharge}

A relationship for overbank flood recharge (Doble et al., 2012) was modified for application to the AWRA system (Van Dijk et al., 2011). Recharge from flooding was mod- elled at a daily time step for seven different catchments for the test period of 1 November 2010 until 31 March 2011. During this time, many parts of eastern Australia experienced severe flooding from tropical rainfall systems.

\subsection{The AWRA system}

The AWRA system is being developed to provide historical, current and future trajectory information about the fluxes and storages of the water balance across the Australian continent (Van Dijk et al., 2011; Vaze et al., 2013). This information is derived from a set of daily meteorological and hydrological observations and underlying spatial information. AWRA is run at a daily time step and consists of three components:

- AWRA-L, a gridded land surface model that estimates daily runoff, infiltration, interception, diffuse recharge and evapotranspiration from satellite and meteorological observations at $0.05^{\circ}$ spatial resolution (van Dijk, 2010; Van Dijk and Renzullo, 2011; Peeters et al., 2013; Vaze et al., 2013);

- AWRA-R, a node-link river routing model that estimates river flows and losses to groundwater from stream beds using inflows from AWRA-L and constrained by observations such as stream gauging and diversions (Frost et al., 2011; Leighton et al., 2011); and

- AWRA-G, a groundwater component model (Crosbie et al., 2011; Joehnk et al., 2012) that calculates lateral flow of groundwater between cells, contributions to and from deep aquifers, groundwater pumping, discharge to the ocean and recharge from overbank flooding.

The model was calibrated against 300 catchments, validated against another 300 catchments and benchmarked independently against recharge, soil moisture, LAI (leaf area index) and ET (evapotranspiration) data sets across the continent. The model was calibrated for 19 parameters with a warm-up period of 1 year. Investigation into the propagation of uncertainties in the forcing data is currently underway, but rigorous quality control of input data has been undertaken. The calibration process is discussed in further detail in Viney et al. (2013).

Whilst AWRA-R will estimate in-channel losses to groundwater, this paper describes the method to be implemented in AWRA-G for estimating recharge from overbank flooding. The methodology described in Doble et al. (2012) was used to provide information about recharge to groundwater during the floods of January 2011 as a proof of concept. 


\subsection{Overbank flood recharge equations}

The Doble et al. (2012) relationship for flood recharge to groundwater was derived from the continuity equation:

$\Delta S=I-Q$,

where the inflow $(I)$ to groundwater is limited by the total aquifer storage available $(\Delta S)$ and the maximum rate of outflow $(Q)$.

The actual infiltration to the system is the minimum of the potential infiltration to the aquifer and the capacity of the aquifer to store and transmit the water, that is $\Delta S+Q$ :

$I_{\text {actual }}=\min (I, \Delta S+Q)$.

The available aquifer storage is calculated as

$\Delta S=d_{\mathrm{gw}} S_{\mathrm{y}} x_{w}$,

where $\left(d_{\mathrm{gw}}\right)$ is depth to groundwater, $S_{\mathrm{y}}$ is the aquifer specific yield and $x_{w}$ is the lateral extent of the flooding. the potential infiltration volume is approximated from a vertical application of Darcy's law:

$I=K_{\mathrm{c}} x_{w}\left(\frac{h_{w}}{d_{\mathrm{c}}}+1\right) t_{w}$,

where $K_{\mathrm{c}}$ is the saturated conductivity of the soil surface layer, $h_{w}$ is the depth of the flood, $d_{c}$ is the thickness of the surface layer and $t_{w}$ is the duration of inundation. The potential volume of water discharging laterally from the aquifer $(Q)$ is approximated as a horizontal application of Darcy's law:

$Q=K_{\mathrm{aq}} d_{\mathrm{aq}} t_{w} \frac{d_{\mathrm{gw}}}{x_{w} / 2}$,

where $K_{\text {aq }}$ is the hydraulic conductivity of the aquifer and $d_{\text {aq }}$ is the saturated thickness of the aquifer.

This relationship may be applied to a gridded landscape model by considering the lateral extent of flooding to be the proportion of the grid cell that is inundated and the duration of the inundation equal to the model's time step. This results in the calculation of the recharge to groundwater per cell over one time step. Thus the parameters $\Delta S, I$ and $Q$ are presented throughout the paper in units of millimetres for each model cell. The landscape model can then be used to distribute this overbank flood recharge to surrounding cells and update water table elevations on a daily or monthly time step.

For the prototype testing of this model before incorporation into AWRA, the water table was not updated daily. Recharge over the floodplain soils was not high enough to raise the groundwater level to the ground surface, therefore the transmission of water through the aquifer was not likely to be a limiting factor for recharge in the seven catchments tested as shown in Doble et al. (2012).

\subsection{Data used in the OFR modelling}

For the application within AWRA-G, the parameters in Eqs. (1)-(5) were calculated from the data sources shown in Table A1.

MODerate resolution Imaging Spectrometer (MODIS) surface reflectance data (MOD09GA and MYD09GA reflectance products) were used to map the extent of open water across the Australian continent. The information was available at twice daily frequency, with a spatial resolution of $250-1000 \mathrm{~m}$.

The MODIS data were used to calculate the percentage of a standard $500 \mathrm{~m}$ by $500 \mathrm{~m}$ cell that is covered by water, also expressed as the open water likelihood or OWL, as a percent (Guerschman et al., 2011). The average open water elevation was calculated by constructing a histogram of the $1 \mathrm{~s}$ DEM within each cell, and selecting the elevation associated with the OWL percentile. This cell elevation is then subtracted from this value to give a depth of flooding (Ticehurst et al., 2009). The MODIS method for calculating OWL and flood depth has previously been tested against gauged river floods in the Condamine-Balonne Catchment (Gouweleeuw et al., 2011).

Threshold OWL limits for flooding of 5,10 and 20\% were implemented into the algorithm to minimise the occurrence of unexplained water coverage, or noise. A flooding threshold of $10 \%$ provided the best reduction of unexplained water coverage, whilst still maintaining accurate representation of observed flood inundation. Results presented in this paper are calculated using a $10 \%$ OWL threshold for flooding. Where cloud presence impacted the MODIS data, or data were not available due to the flight path of the satellite, data from the previous day were used.

Information on surface soil (clogging layer) thickness and hydraulic conductivity at a continental scale were provided by the Australian Soil Resource Information System (ASRIS) database (Johnston et al., 2003). These data were derived by linking tabulated relationships between soil classification for the topsoil and first subsoil, with tables of soil properties.

The initial water table was derived from the minimum $9 \mathrm{~s}$ DEM (digital elevation model) elevation within each $0.05^{\circ}$ AWRA grid cell (Joehnk et al., 2012). Depth to groundwater was calculated from the average DEM elevation within an AWRA grid cell, minus the initial water table. As an initial approximation, aquifer specific yield, hydraulic conductivity and thickness were estimated using aquifer classifications (Groundwater Flow Systems) (Coram et al., 2000) and surface geology maps (Liu et al., 2006; Raymond et al., 2007a, b; Stewart et al., 2008; Whitaker et al., 2007, 2008) fully described in Joehnk et al. (2012). Specific yield ranged between 0.03 and 0.3 and transmissivity (aquifer hydraulic conductivity multiplied by aquifer thicknesses) between 0.01 and $100 \mathrm{~m}^{2} \mathrm{~d}^{-1}$. 


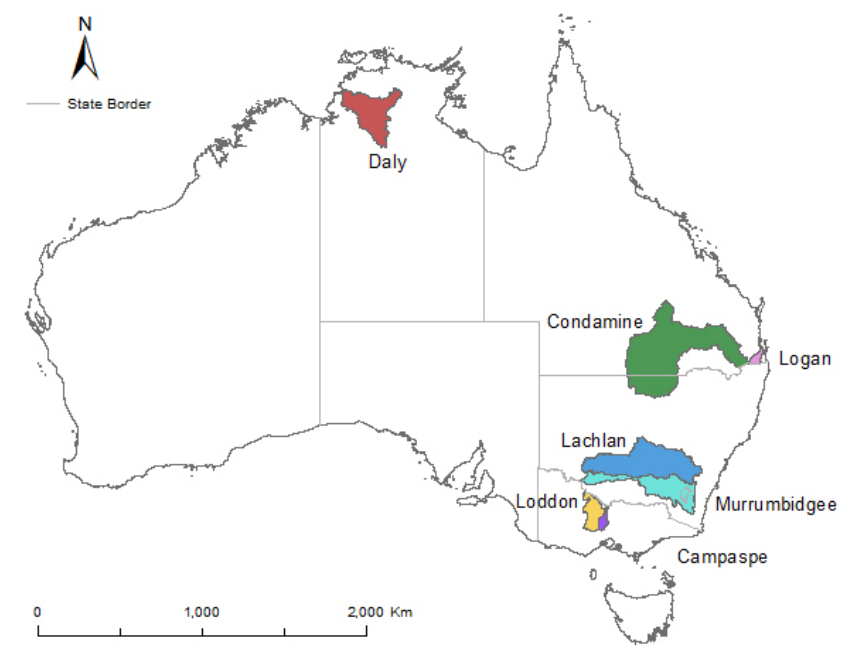

Fig. 1. Location map for the catchments used in this study.

Equations (2)-5) were coded in $R$, and the script run with a daily time step from 1 November 2010 until the 31 March 2011, a time frame that adequately captured the 2010/2011 floods for all of the catchments modelled. Recharge to groundwater was calculated for each day, then summed for the 5 months to give total recharge for each of the floods.

\subsection{Test catchments}

Seven catchments were chosen within Australia from areas that are climatically distinct and within regions that experienced overbank flooding during the period from November 2010 until March 2011 (Fig. 1). The catchments ranged from a tropical savannah environment in northern Australia, to sub-tropical, arid and temperate catchments within the Murray Darling Basin of south-eastern Australia. The hydrological characteristics of the catchments are outlined in Table 1.

Shallow bore hydrograph data were available for the Loddon, Campaspe, and Condamine catchments for the period modelled. The Loddon catchment was selected for more detailed study of point-scale recharge modelling and catchment-scale recharge estimates due to the higher density of bores available for analysis within the catchment.

\subsection{Estimation of recharge at a point scale}

To validate the results from the OFR modelling with estimations from field data, recharge was calculated for the Loddon, Campaspe and Condamine catchments from shallow bore hydrographs using the water table fluctuation method. In the Daly catchment, bore information was too sparse for rigorous analysis. In the Lachlan and Murrumbidgee catchments, bore information for shallow aquifers was not publicly available. Frequently logged data were not available for any bores within these catchments. Recharge was therefore calculated from bores monitored manually, approximately once every 1-2 months.

Databases for all groundwater bores in the Loddon, Campaspe and Condamine catchments were selected with the following criteria:

- screen depths of less than $50 \mathrm{~m}$;

- more than three data readings between 1 November 2010 and 31 March 2011; and

- observed long-term responses to recharge.

Groundwater recharge to bores in each of the catchments was calculated using bore observations before and after the flood, multiplied by specific yield, as a best approximation of the water table fluctuation method (Healy and Cook, 2002; Crosbie et al., 2005). The observation frequency for the bores in each of the catchments was not high enough to allow the use of the full water table fluctuation method. Estimation of recharge for each bore was compared with the modelled recharge at the bore location.

\subsection{Comparison of recharge for different soil and flood conditions at a point scale}

The flood recharge estimated using the simple OFR equations is only one component of the total groundwater recharge. When comparing this to the recharge estimated using the water table fluctuation method it is likely to underestimate recharge because diffuse recharge due to rainfall and irrigation is not taken into account. To investigate the contribution of recharge from overbank flooding, rainfall and irrigation, simulations were performed using the 1-D soilvegetation-atmosphere transfer model WAVES (Zhang and Dawes, 1998).

The simulations were conducted using climate data (Jeffrey et al., 2001) from Kerang, toward the north of the Loddon catchment, using four soil and vegetation combinations that are common in the area. The two soils simulated were a Sodosol and a Vertosol (Isbell, 2002), with the Vertosol being the more common soil type in the catchment floodplain. The vegetation types simulated were annual and perennial pastures. The model used a free draining lower boundary condition with a $4 \mathrm{~m}$ soil column. This model setup simulated conditions with a groundwater depth greater than $4 \mathrm{~m}$. The model parameters were as used in Crosbie et al. (2010) for this region. The four scenarios investigated were

- diffuse recharge due to rainfall only;

- diffuse recharge due to rainfall and flood recharge from a flood of $300 \mathrm{~mm}$ depth for 6 days starting 14 January 2011 ;

- diffuse recharge due to rainfall and irrigation due to the application of $10 \mathrm{ML} \mathrm{ha}^{-1} \mathrm{yr}^{-1}$ which is typical for the dairy industry in this area (DSE and DPI, 2004); and 
Table 1. Hydrological characteristics of each of the seven catchments used in this study.

\begin{tabular}{|c|c|c|c|c|c|}
\hline Catchment & $\begin{array}{l}\text { Approximate } \\
\text { area }\left(\mathrm{km}^{2}\right)\end{array}$ & $\begin{array}{l}\text { Approximate } \\
\text { annual } \\
\text { rainfall }(\mathrm{mm})^{1}\end{array}$ & $\begin{array}{c}\text { Approximate } \\
\text { annual pan } \\
\text { evaporation }(\mathrm{mm})^{2}\end{array}$ & $\begin{array}{l}\text { Terrain/vegetation/ } \\
\text { land use/comments }\end{array}$ & $\begin{array}{l}\text { Overbank floods } \\
\text { reported }\end{array}$ \\
\hline Loddon River & 15500 & 450 & 1500 & Temperate, winter dominant rainfall & Kerang, etc., January 2011 \\
\hline Campaspe River & 3500 & 550 & 1400 & Temperate, winter dominant rainfall & Kyneton, Echuca, January 2011 \\
\hline Murrumbidgee River & 49000 & 500 & 1800 & Variable, from sub-alpine (east) to arid inland (west) & Wagga Wagga, December 2010 \\
\hline Lachlan River & 89000 & 450 & 2000 & Variable, from sub-alpine (east) to arid inland (west) & Forbes, December 2010 \\
\hline $\begin{array}{l}\text { Barwon-Condamine-- } \\
\text { Culgoa rivers }\end{array}$ & 167000 & 500 & 2200 & Inland, summer rainfall, ephemeral streams & Dalby, Condamine, January 2011 \\
\hline Logan-Albert rivers & 4300 & 1000 & 1600 & Sub-tropical & Beaudesert, January 2011 \\
\hline Daly River & 58600 & 1000 & 2700 & Tropical savannah & $\begin{array}{l}\text { Daly River township, } \\
\text { from } 30 \text { December } 2011\end{array}$ \\
\hline
\end{tabular}

${ }^{1}$ Bureau of Meteorology, Average annual rainfall map. Note there is high variation within the catchments, particularly the Murrumbidgee, Lachlan and Condamine. ${ }^{2}$ Bureau of Meteorology, Average annual pan evaporation map. Note there is high variation within the catchments, particularly the Murrumbidgee, Lachlan and Condamine.

- diffuse recharge due to rainfall and irrigation combined with the flood described above.

The daily output of the model was aggregated to the period covering November 2010-March 2011 as an aid to understanding the differences in the recharge estimates from the water table fluctuation method and the simple overbank flood equations.

\subsection{Estimation of recharge at a catchment scale}

In order to validate the modelled recharge at a catchment scale, the change in aquifer storage was calculated for the Loddon catchment through interpolated water table surfaces derived from shallow bore observations. A multi-variate version of kriging with external drift (KED) (Peterson et al., 2011) was used to derive water table surfaces for the latest reduced water level reading before 12 January 2011 and the first reading after 31 March 2011. The method used a range of deterministic external drivers (e.g. topography and climate) to improve the mapping of the water table at a regional scale and provide estimates of spatial uncertainty.

Maps of water table elevation before and after the January 2011 flooding were produced, and the change in storage calculated from the difference between the water table elevation maps multiplied by the spatial map of specific yield used in the modelling described above.

In areas of data scarcity, a future option for recharge estimation at a catchment scale might be from the Gravity Recovery And Climate Experiment (GRACE) gravity data sets. Data from the GRACE satellite have the potential to provide information on groundwater fluctuations at a catchment or continental scale, with a footprint currently of around $300 \mathrm{~km}$. Improvements in the data resolution are likely with the launch of new satellites, scheduled for 2017. Currently, however, the resolution of GRACE does not have the level of detail required for the model with $500 \mathrm{~m} \times 500 \mathrm{~m}$ discretisation used in this study. The high uncertainty associated with the inverse modelling required to transform gravity measurements to water responses also leads to inaccurate predictions of groundwater fluctuation at a continental scale. This lim- its the usefulness of the data at this stage for validating water balances. Previous work undertaken by authors of this paper indicated that the GRACE data did not reliably represent groundwater variations for the majority of Australia (Tregoning et al., 2012).

\section{Results}

The OFR results in the Loddon, Campaspe and Condamine catchments were compared with recharge estimated from bore responses. Flood recharge in the Loddon catchment was also compared with recharge modelled at a catchment scale using interpolated maps of bore responses. Point-scale modelling of recharge for different soil, vegetation, irrigation and flooding characteristics using WAVES was used to determine the relative contribution of OFR to the water budget.

\subsection{Daily flood recharge values}

Daily recharge to groundwater in the Loddon catchment ranges from 0 to approximately $20 \mathrm{~mm} \mathrm{~d}^{-1}$, and is highest and more widespread immediately after the rainfall between 10 and 14 January 2011 (Fig. 2). The daily recharge data indicate that the flooded area progressed down the catchment with time, in some areas leaving water isolated from the river in ponds. Flood recharge appears to have occurred in large, widespread areas, with a small amount of isolated, unexplained recharge further from the river.

\subsection{Total OFR results}

Widespread recharge is indicated across the floodplain areas of the Loddon catchment, in the northern part of the Campaspe catchment and southern and eastern parts of the Condamine catchment, associated with the major flooding that occurred in these regions (Fig. 3). The braided nature of the lower Condamine River is evident in the OFR output. Despite the threshold for flooding implemented within the algorithm, there is still unexplained recharge, that is, false positive occurrences of recharge in all of the catchments, and 

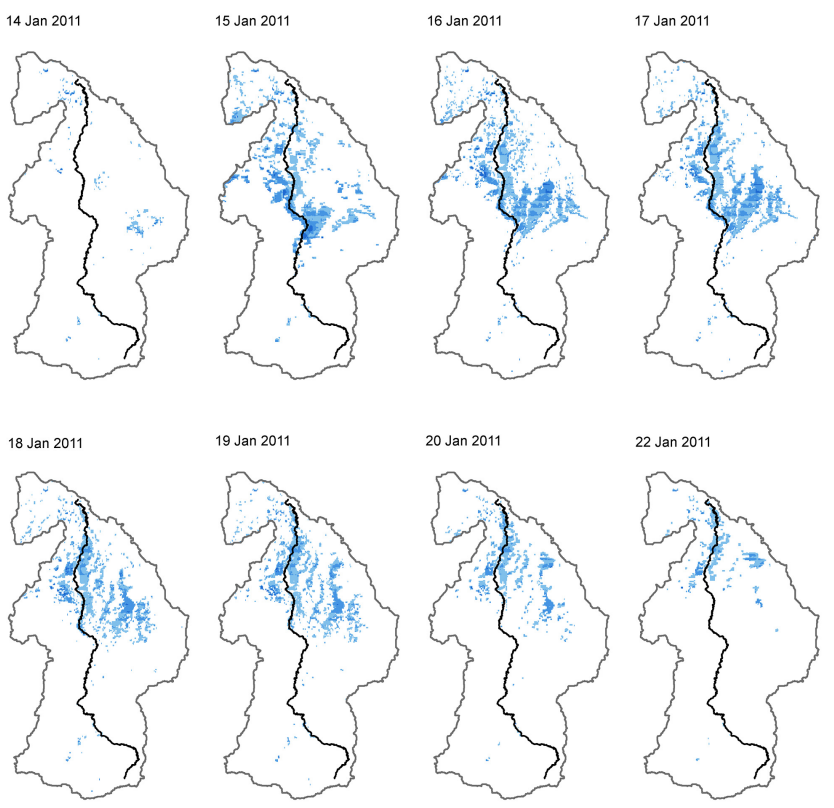

Recharge (mm/d)

$0 ., 1,3,10,3^{30}, 7^{30}$

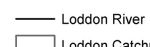

$\stackrel{0}{2}+\perp^{5}$ 100 Kilometers

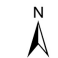

Fig. 2. Time series of flood recharge maps for the Loddon catchment showing the progression of flood recharge down the catchment with time.

in particular the Condamine, Daly and Lachlan catchments. There is some confidence that this represents real recharge in areas where the recharge pixels are concentrated together, for example, in small parts of the Murrumbidgee catchment along the river and at the western (outflow) end of the Daly River. Overbank flood recharge was difficult to discern from unexplained flooding in the Logan or Lachlan catchments.

There is little evidence of flood-induced open water in the Lachlan, Daly, Logan and Campaspe catchments. This may have been due to the cloud cover and null data due to satellite synchronisation. In the Lachlan catchment, cloud cover and areas of no satellite signal were found to obstruct mapping of open water bodies early in the flood period (1-9 December) and this may have led to the flood peak being missed (Fig. 4). There are, however, very few open water bodies observed in the period immediately following the flood (11-31 December), and very little change in these water bodies in time. This suggests that even with perfect satellite coverage and absence of clouds, detection of open water bodies is likely to have been underestimated.

\section{Tests against independent data}

The modelled OFR data were compared against recharge calculated at a point scale, at a catchment scale, and with pointscale recharge modelled with the WAVES model.

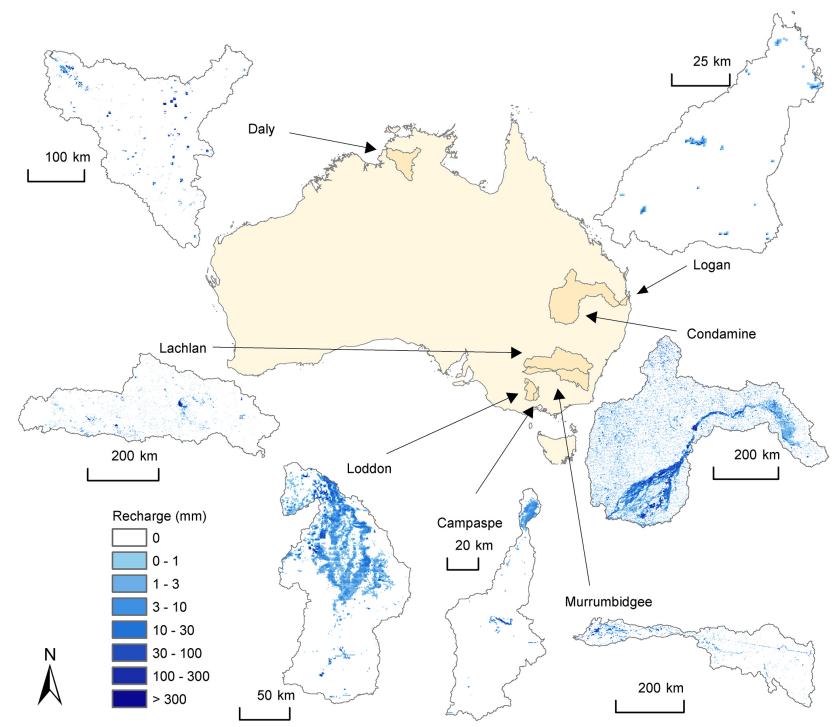

Fig. 3. Maps of the flood recharge for the seven catchments for the floods between 1 November 2010 and 31 March 2011.

\subsection{Comparison of modelled and estimated recharge at a point scale}

There appears to be a nominal increase in recharge calculated from bore records in the floodplain region of the Loddon and Campaspe catchments (the area indicated to be flooded from modelled data) compared with bores in other areas; for example the southern highland (Fig. 5). Flooded areas were defined by a modelled OFR of greater than $0.1,0.5$, or $1 \mathrm{~mm}$ over the flood period (box plot of log recharge shows results for a $1 \mathrm{~mm}$ threshold), and the log of negative recharge redefined to zero (Fig. 6). The box plots were found to be very insensitive to the threshold for flooding within this range. A comparison of recharge histograms for flooded and nonflooded areas (Fig. 7) showed that although there appears to be little difference in the distribution of the high end of the data range, there were many more occurrences of bores with zero or very low recharge that were found in the non-flooded areas. A greater number of bore observations in non-flooded areas may improve this analysis.

The density of bores was higher in the floodplain region than in the highland, a result of the exclusion of deeper bores from the analysis. While deeper bores were excluded so that only shallow recharge in the unconfined aquifer was accounted for, the inclusion of deeper bores from the highland in the analysis was found to increase the difference between recharge in flooded versus non-flooded areas.

High rates of recharge were modelled and measured from bore responses in the northern floodplain section of the Campaspe catchment (Fig. 5). There were very few shallow bores in the highland part of the catchment with which to compare non-flooded information. High rates of recharge calculated from bore responses were still found in areas not modelled 


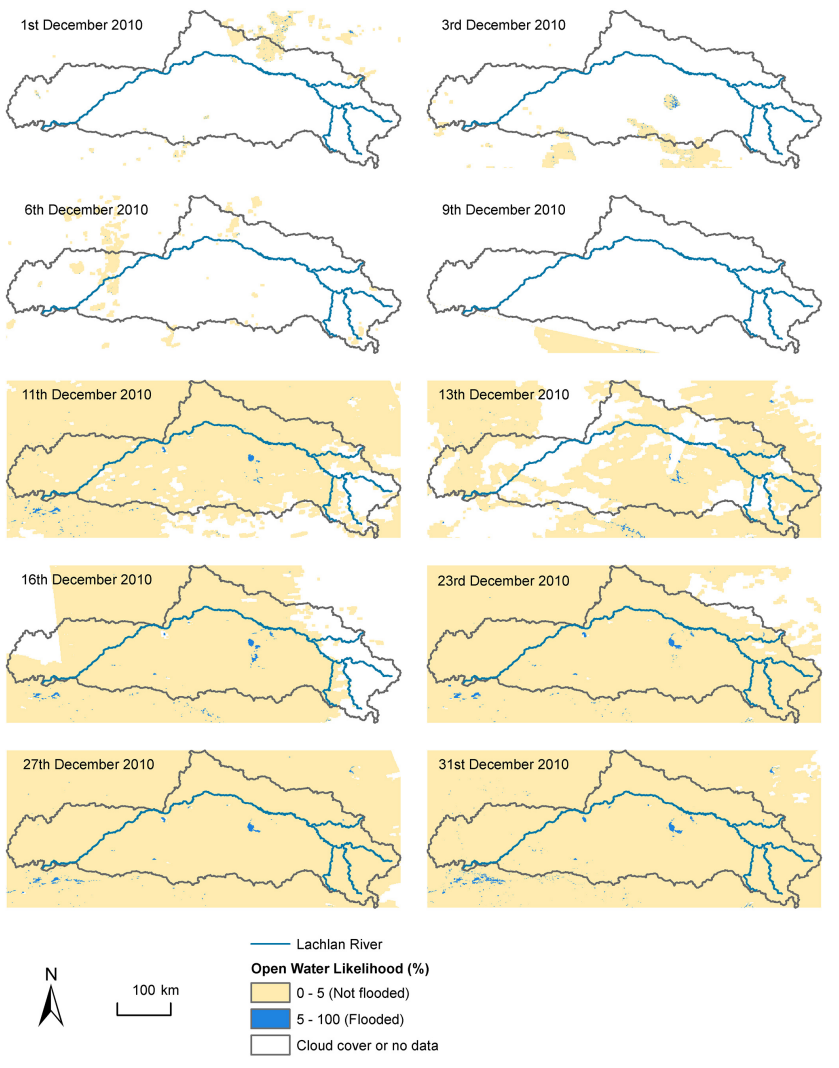

Fig. 4. OWL in the Lachlan catchment during flooding in December 2010. Flooded areas detected by MODIS data are indicated in dark blue. Cloud coverage and no data signal are indicated in white. Null data due to no satellite signal (indicated by straight line boundaries between data and no data) are present on 9 and 16 December. Although there was a large interruption of the data set just prior to and during the start of the flooding (1-9 December), very few areas of standing water were observed immediately after the rainfall event (post-11 December).

to be recharging due to inundation from overbank floods. A comparison of recharge histograms for flooded and nonflooded areas (Fig. 7) shows higher recharge and the absence of locations with zero recharge in flooded areas, although the low number of observations in flooded areas reduces the confidence in these results $(n=80)$.

In the Condamine catchment, there was evidence of groundwater recharge in bores in the eastern part of the catchment that is close to, but does not align with areas of modelled recharge (Fig. 8). Using $1 \mathrm{~mm}$ OFR to separate flooded and non-flooded areas, both the box plots (Fig. 6) and a comparison of hydrographs (Fig. 7) showed very little difference between the two data sets. Many of the shallow bores in the catchment are located in the highly permeable volcanic soils surrounding the upland valley, and were probably not flooded, but showed a response to the high rainfall in this area. The spatial frequency of bore records in the west-
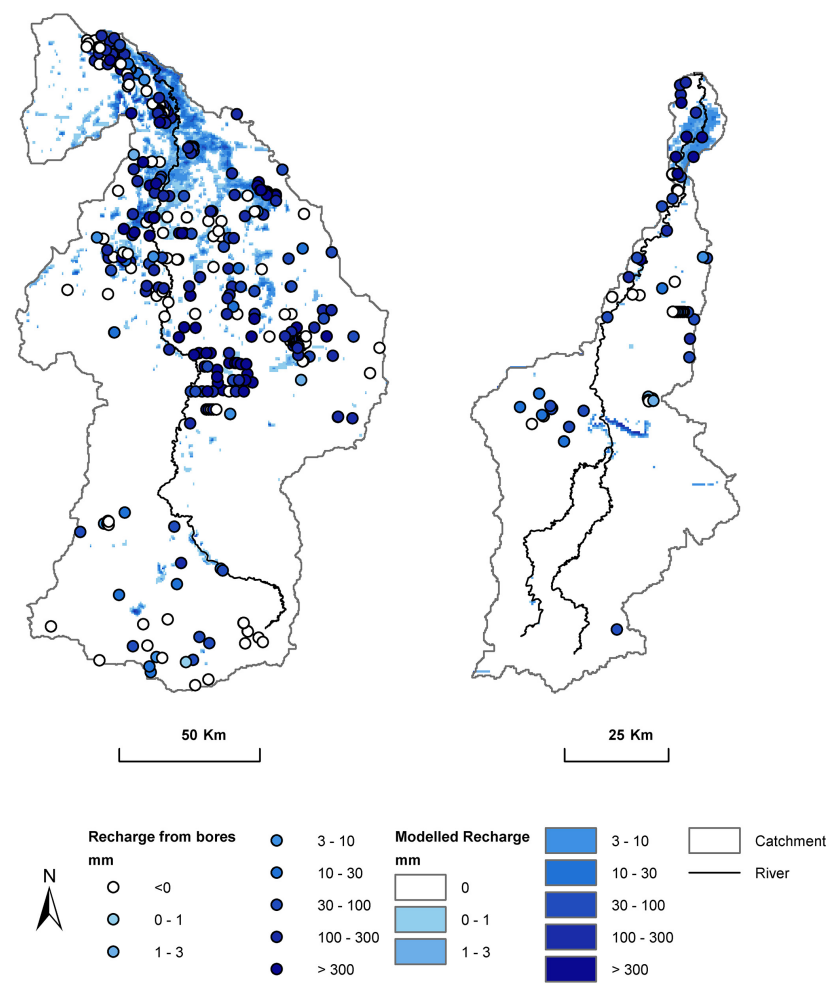

Fig. 5. Modelled OFR and recharge calculated from bore responses for the Loddon and Campaspe catchments.

ern and central parts of the catchment was too low to identify any areas of recharge during the modelled period.

\subsection{Comparison of OFR recharge with WAVES recharge}

For non-irrigated soils there is approximately one to two orders of magnitude difference between WAVES-modelled recharge in flooded and non-flooded areas (Table 2, Fig. 9). The maximum recharge under flood conditions on Vertosol soils with annual vegetation was $200.9 \mathrm{~mm}$ over the 5 months that were modelled. This is of the same order of magnitude as the maximum value of modelled OFR in the Loddon catchment $(438 \mathrm{~mm})$. In flood conditions, recharge estimated with WAVES ranged from 136 to $266 \mathrm{~mm}$. On average this is somewhat higher than the modelled OFR, which was generally within a range of $1-100 \mathrm{~mm}$, but it does include recharge from rainfall. The proportion of rainfall that recharges groundwater would be increased by the presence of saturated soils under flood conditions; therefore the volume of flood recharge is not directly calculable from the difference between columns 1 and 2 in Table 2. However, from this calculation, the maximum attributable recharge due to flooding can be inferred to be between 135 and $220 \mathrm{~mm}$.

For the irrigated scenarios, recharge under flood conditions is between two times to two orders of magnitude more than non-flooded conditions. The maximum recharge rate is 
Table 2. Comparison between point-scale recharge in millimetres for the modelled period under the two most common soil types, vegetation types and irrigated vs. non-irrigated land, for flooded and non-flooded conditions.

\begin{tabular}{lrr}
\hline & $\begin{array}{r}\text { Flooded } \\
\text { recharge }(\mathrm{mm})\end{array}$ & $\begin{array}{r}\text { Not flooded } \\
\text { recharge }(\mathrm{mm})\end{array}$ \\
\hline Sodosol, annual & 265.8 & 45.1 \\
Sodosol, perennial & 206.5 & 9.0 \\
Vertosol, annual & 200.9 & 6.7 \\
Vertosol, perennial & 135.7 & 0.8 \\
Sodosol, annual, irrigated & 646.7 & 378.4 \\
Sodosol, perennial, irrigated & 442.3 & 138.4 \\
Vertosol, annual, irrigated & 595.6 & 25.8 \\
Vertosol, perennial, irrigated & 459.1 & 1.2 \\
\hline
\end{tabular}

much higher than that predicted by the OFR modelling, but includes regular irrigation throughout the flood.

\subsection{Comparison of modelled and estimated recharge at a catchment scale}

The majority of the Loddon catchment experienced an increase in water table elevation, as indicated by positive change in storage estimated at a catchment scale from interpolated bore responses (Fig. 10). The northern part of the catchment showed a higher change in groundwater storage from recharge, due to both the flooding in this region and the higher specific yield of the shallow aquifer. There was higher variability in the estimated change in storage in the northern floodplain-half of the catchment, associated with the large number of bores in this region. An area of high positive change in storage was found in the centre of the catchment, an area that was inundated by flooding and was associated with a comparatively more hydraulically conductive Sodosol soil classification.

The change in storage within the Loddon catchment over the modelled period was estimated from the difference in water table elevation to be $1074 \mathrm{GL}\left(1 \mathrm{GL}=10^{6} \mathrm{~m}^{3}\right)$. This compared with a modelled volume of recharge from overbank flooding of $29 \mathrm{GL}$. It is acknowledged, however, that the change in storage estimated from bore responses included recharge from rainfall, river leakage, irrigation and groundwater pumping. The total volume of overbank flood recharge can therefore be expressed as

$R_{\mathrm{OF}}=\Delta S-R_{\mathrm{R}}-R_{\mathrm{RL}}-R_{\mathrm{I}}+P$,

where $R_{\mathrm{OF}}$ represents overbank flood recharge, $\Delta S=$ change in storage, $R_{\mathrm{R}}$ represents rainfall recharge, $R_{\mathrm{RL}}$ represents river losses, $R_{\mathrm{I}}$ represents irrigation recharge and $P$ represents groundwater pumping.

While groundwater recharge from river losses and pumping rates are currently being analysed for the Loddon catchment and are not yet quantified, recharge volumes from rainfall and irrigation were estimated from the WAVES modelling undertaken (Table 2). For a catchment area of
$15745 \mathrm{~km}^{2}$, approximately $830 \mathrm{GL}$ of recharge is provided by rainfall and irrigation, leaving a residual of $200 \mathrm{GL}$ for river losses and overbank flood recharge. This is within reasonable agreement with the $29 \mathrm{GL}$ estimated from the OFR modelling plus direct losses through the river bed during this period.

It should be noted that the water budget presented, while it is the best possible for the data available, is not an accurate representation of the water budget during flood conditions. Due to the changes in soil saturation during flood inundation, irrigation and rainfall, there is a high uncertainty associated with using a linear water balance.

\section{Discussion}

\subsection{How important is the overbank flood recharge process?}

Given the uncertainty in modelling groundwater recharge from overbank flooding, and the input data required to do so, it is reasonable to ask whether there is value considering this process in large-scale water balance models. Comparison between the OFR modelling and WAVES modelling suggested that overbank flood recharge is not an insignificant volume of recharge to a catchment. In the Loddon catchment, overbank flood recharge represented a minimum of $4 \%$ of the total recharge over the whole catchment for the duration of the modelling, and $15 \%$ of the riparian recharge for this period. It is also likely that these proportions were underestimated by the method used. Although the overbank flood recharge volume was less than diffuse rainfall recharge and river loss to groundwater over time, it is likely to be of a high enough volume to warrant further investigation in highly allocated groundwater systems.

The modelling had a relatively low computational effort, and had the same data requirements as other parts of the AWRA modelling system - particularly the river budget component of AWRA-R. Including the overbank flood recharge process in water balance modelling will assist in 
Observed recharge from shallow bores Loddon

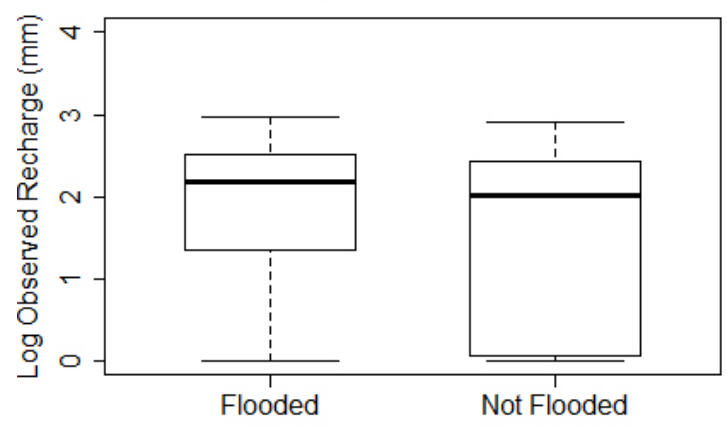

Observed recharge from shallow bores Campaspe

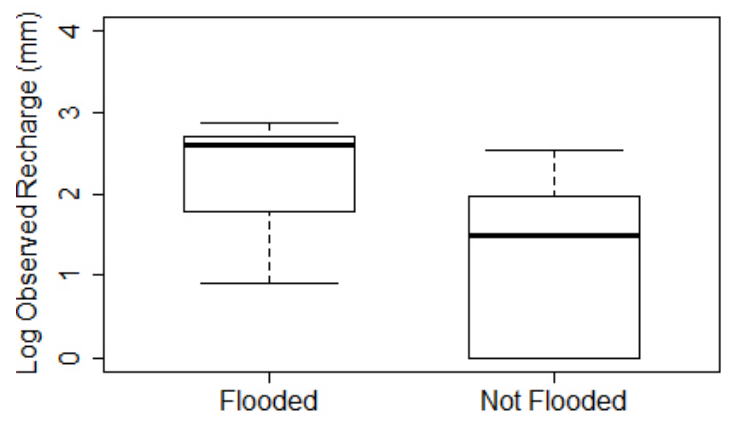

Observed recharge from shallow bores Condamine

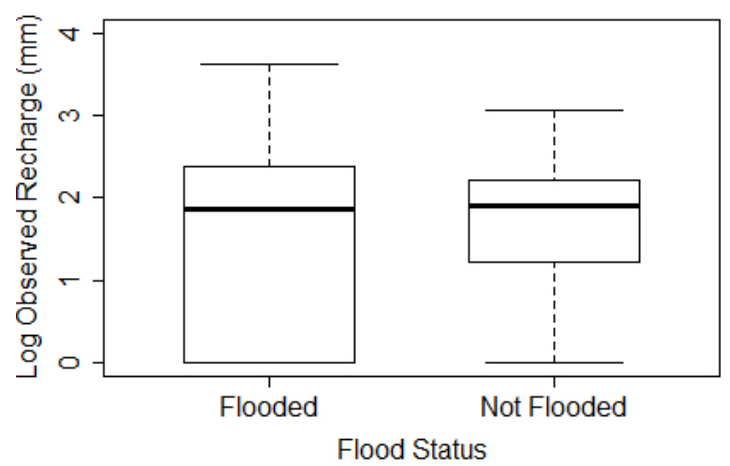

Fig. 6. Box plots of log recharge calculated from bore responses in flooded versus non-flooded areas (defined by modelled OFR greater than or less than $1 \mathrm{~mm}$ over the flood period) for the Loddon, Campaspe and Condamine catchments. A two tailed $t$ test with unequal variance indicated no statistical significance between the means for the Loddon catchment ( $p=0.08)$, significant difference for the Campaspe catchment $\left(p=2 \times 10^{-5}\right)$, but no statistical significance for the Condamine catchment $(p=0.77)$.

reducing the uncertainty in both river budgets and groundwater budgets, and the volume of water attributable to lumped transmission loss parameters.

The accuracy of the process will be improved as it is incorporated within the AWRA system and is linked with other river and groundwater processes and feedbacks. In particular,
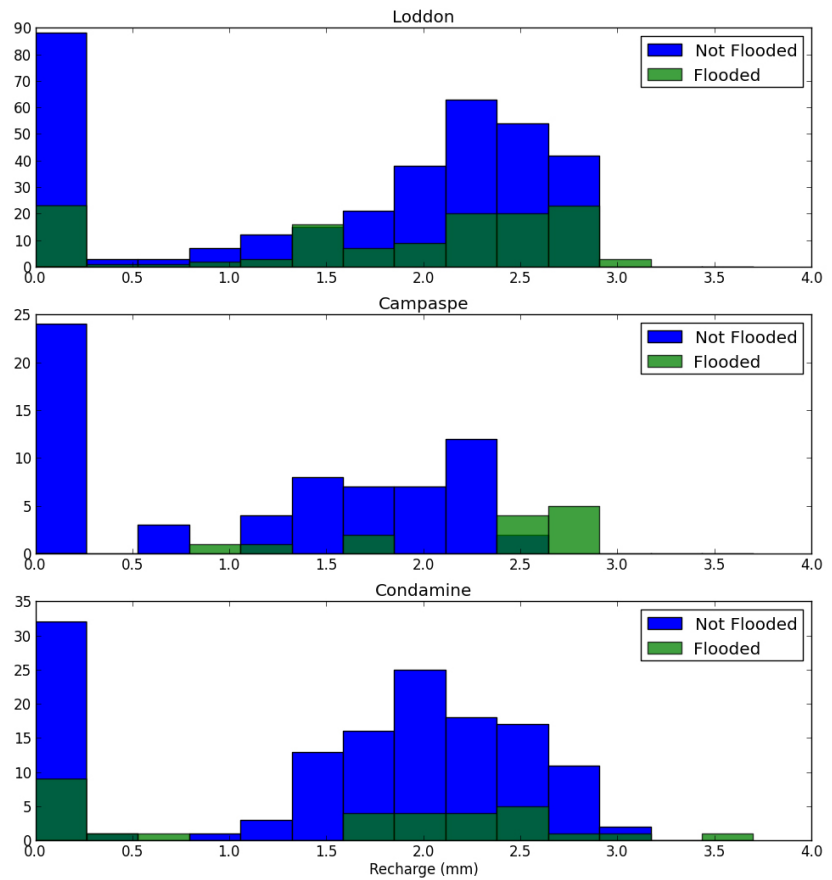

Fig. 7. Comparison of histograms for recharge calculated using the WTF method in flooded and not flooded areas of the Loddon, Campaspe and Condamine catchments.
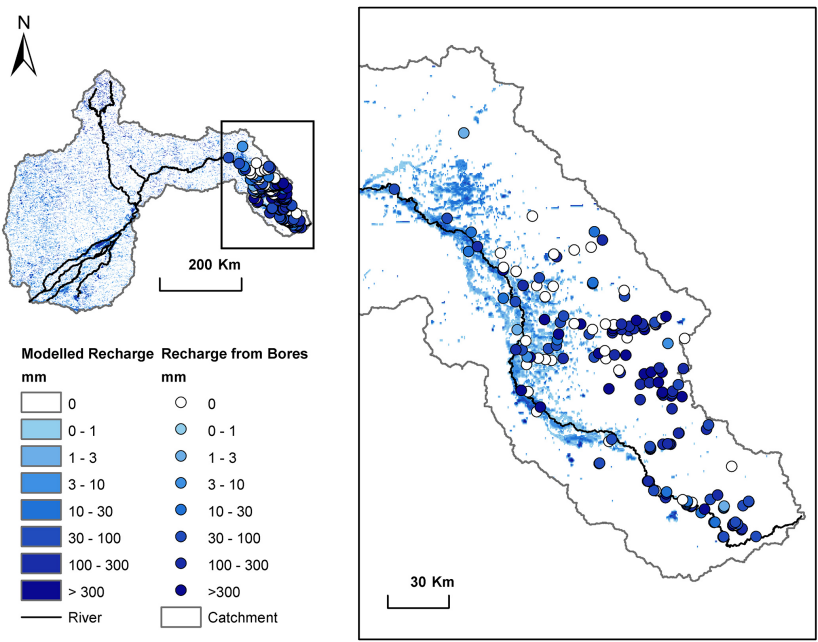

Fig. 8. Modelled OFR and total recharge calculated from bore responses for the Condamine catchment.

the addition of lateral flow between cells will increase the accuracy of the physical representation of the process. Accuracy and confidence in the modelling will also be improved with advances in the development of the input data.

\subsection{Performance of the simple OFR model}

The comparison between modelled overbank flood recharge and recharge calculated from bore observations, point-scale 


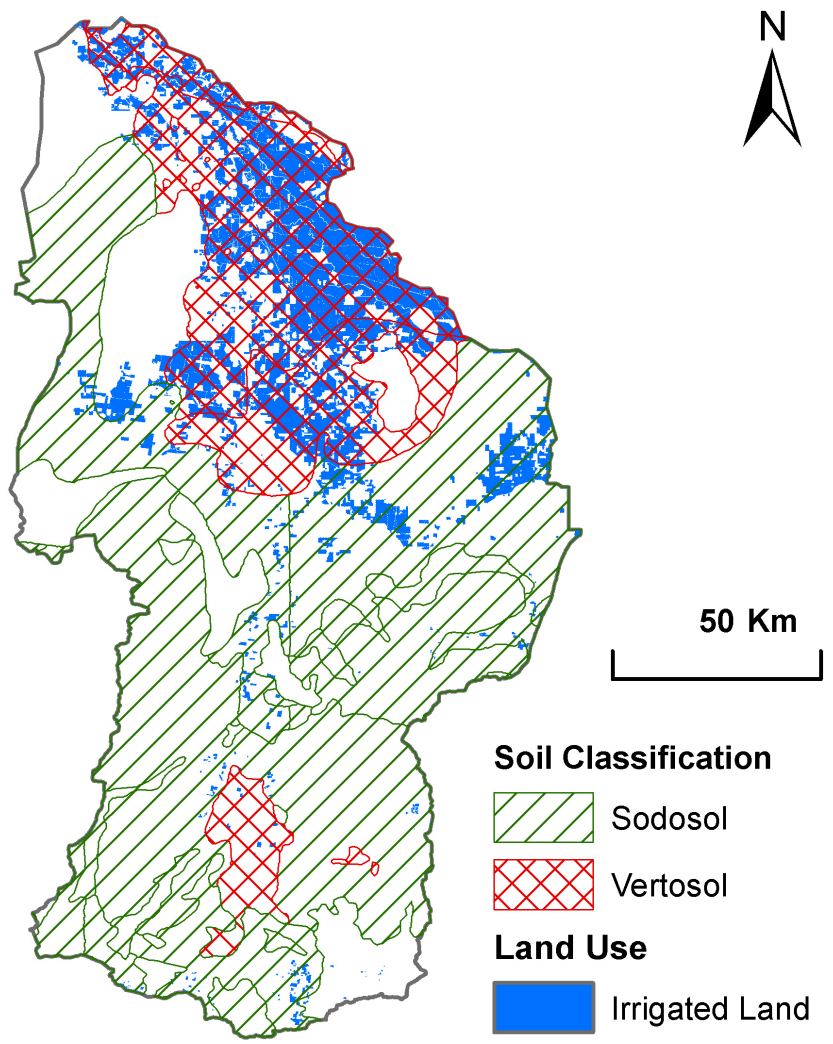

Fig. 9. Soil types and irrigation coverage within the Loddon catchment.

modelling and catchment-scale groundwater surface changes suggests that there is still some work to do to get the absolute values of flood recharge to agree. Each of the three methods used in the validation shows that the algorithm for OFR appears to somewhat under-predict recharge from flooding. These three methods, however, do include diffuse recharge and recharge directly from river losses, and separating OFR from the other types of recharge is difficult. Spatially, some of the catchments have patterns of recharge that "look right", that generally follow the river course and are most expansive around floodplain areas. Presence of OFR, however, does not necessarily match borehole estimates on a point by point basis. This may be for a number of reasons, including smallscale heterogeneities, recharge from nearby infiltration and the coarser-scale nature of the continental-scale soil mapping and data used as inputs to the model.

For the Loddon catchment, the recharge predicted by the OFR modelling was less than that estimated from pointscale bore responses, point-scale WAVES modelling and catchment-scale changes in groundwater storage. Though a formal calibration or validation process was not possible, the OFR modelling was found to under-predict recharge in the Loddon catchment. This under-prediction was likely to be due to limitations in both the flood coverage and depth information and the soils data used. There was no significant cor-

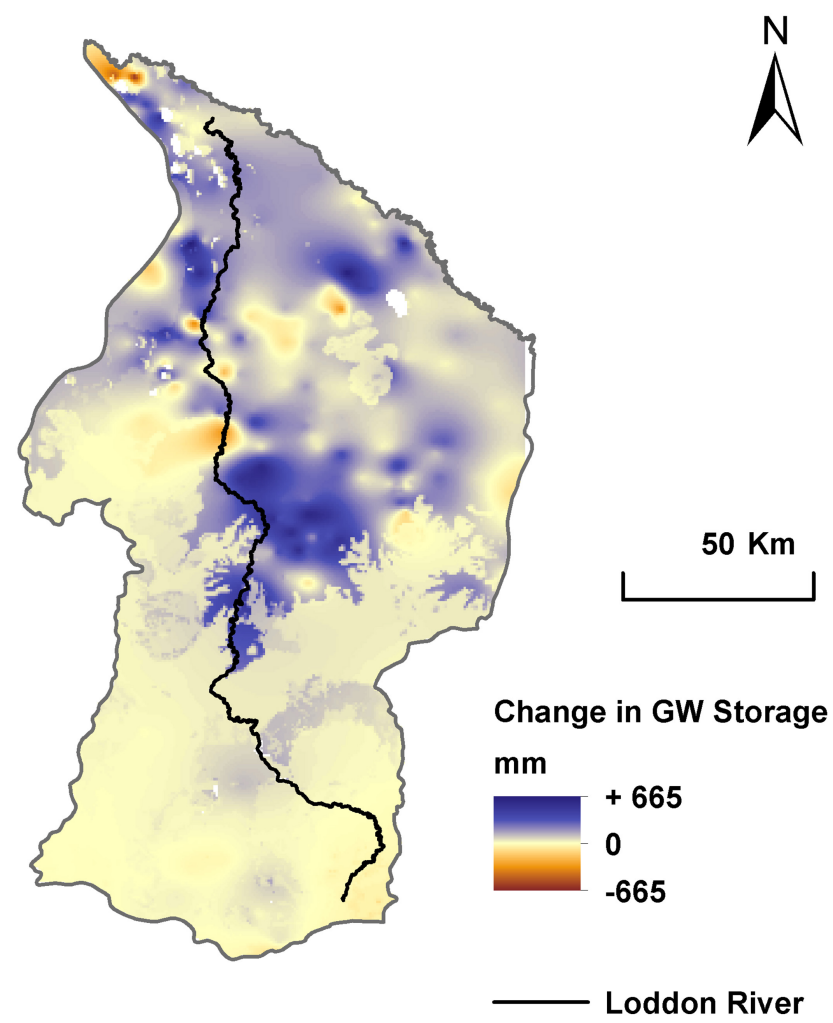

Fig. 10. Change in storage at a catchment scale estimated from interpolated bore responses on 1 November 2010 and 31 March 2011.

relation between modelled and estimated recharge at a point scale. However, confidence was gained in the spatial distribution of the modelled results through

- being able to spatially distinguish flooded and nonflooded areas from bore responses using the modelled prediction of areas experiencing flood recharge;

- the same order of magnitude of recharge obtained with point-scale WAVES modelling in flooded areas; and

- the same order of magnitude volumes of recharge being obtained from a water balance of the change in catchment storage for the modelled period.

In the Campaspe catchment, modelled recharge could be used to spatially distinguish flooded and non-flooded areas from bore hydrographs, albeit with a relatively low number of observation points $(n=80)$. Modelled recharge was lower than that estimated from bore responses. For the Condamine catchment, the areas of modelled flood recharge and recharge estimated from bore responses did not align spatially. Soil information used in the modelling indicated a thinner clogging layer and higher hydraulic conductivity in the region of high estimated recharge, but there was no flooding indicated in this region by the MODIS data. The large bore response in this area is likely to be due to rainfall recharge on the 
conductive volcanic soils present in the area. OFR was not identified in the Lachlan, Daly or Logan catchments as no major flooding was detected in these catchments from satellite imagery, despite floods being indicated in stream hydrographs and news reports.

Unexplained recharge was present in all catchments due to false positive indications of flooding from the satellite imagery, despite attempting to mask out smaller, isolated incidences of flooding detected by MODIS using a threshold to flood parameter. Advances in the processing of the MODIS data are currently underway, which should improve the detection of flood inundation. Other methods for mapping the presence of surface water at large scales are also being developed, for example Westerhoff et al. (2013). The use of river hydrographs and digital elevation models has also been used to successfully map floodplain inundation (Overton, 2005; Bates and De Roo, 2000).

\subsection{Using continental-scale data sets}

While the OFR modelling was able to produce reasonable estimates of groundwater recharge from flood inundation, confidence in the spatial distribution of recharge was limited by the quality of the spatial data currently available. There were no available flood inundation mapping and soil properties at a continental scale.

The flood inundation and depth data tended to exhibit a large amount of unexplained recharge and large spatial variations between daily observations, although the use of the threshold to flood parameter was able to reduce this. Cloud cover is also recognised as being a major issue with MODIS9 data (Long and Singh, 2010). Cloud coverage in some catchments during the modelled period required flood inundation from the previous day to be used, and the Daly catchment in particular had a high proportion of null data (due to satellite location and/or orientation) for the period of flooding. Originally the research looked at using low frequency passive microwave data (AMSR-E) where null data are present to fill in these data gaps more effectively. However, the method was limited by a spatial resolution of between 5 and $70 \mathrm{~km}$ and the signal is also known to be also distorted by precipitation. Research into an improved passive microwave water map is currently being undertaken, but it is not yet at a stage that could be used for this project. In this case the most appropriate method for dealing with lack of flood data associated with cloud coverage or where satellites were not synchronised was thought to be to replace the missing data with the most recent data that were unaffected by cloud or flight path.

Another remote sensing method that may be appropriate for the detection of open water under cloudy conditions is the use of synthetic aperture radar (SAR), although some effort is required in the extremely precise calibration (Dellepiane and Angiati, 2012; Hostache et al., 2009; Martinis et al., 2011).

Though testing of the MODIS methodology resulted in a good match between modelled and gauged flood volumes, there were variations in the hydrograph decline due to storage of open water within irrigation infrastructure on the floodplain. There were also ongoing issues with unexplained recharge associated with saturated soil surfaces. Despite this, the satellite imagery provided the most appropriate data set at a continental scale. Further development of the processing method for the satellite imagery is expected to improve accuracy in this data set (Guerschman et al., 2010; Ticehurst et al., 2009; Guerschman et al., 2011).

The ASRIS database and estimates of aquifer conductivity, thickness and specific yield provided information on aquifer and surface soil types and their hydraulic characteristics at a continental scale. Although the hydraulic conductivity information was derived from spatially extrapolated soil classes and tabulated soil properties, there was still uncertainty associated with the upscaling of point measurements to a catchment scale, and in the assignment of hydraulic conductivity and specific yield to the aquifer types. Spatial and temporal variability in soil hydraulic properties can be high, even within the same soil class. In particular, the hydraulic conductivity of Vertosol and Sodosol soils on floodplains may change from initially quite high, as water infiltrates through cracks and preferential pathways, to very low as the clay saturates and swells and preferential pathways seal up.

To maximise accuracy and distinguish flood infiltration from other forms of recharge, recharge from flooding should ideally be estimated from bore hydrographs with sub-daily observations. As there were not enough frequently logged water level data for the catchments modelled, recharge was calculated from bores with less frequent observations. Although this was able to provide much larger spatial coverages of three of the catchments, there were some issues that arose with the low frequency of data, including recharge being underestimated due to the peak groundwater elevation not being captured. Overestimation of vertical flood recharge could result from

- direct infiltration down the bore casing, although any records with unusually large rises in the water table were discarded;

- the inclusion of diffuse recharge from rainfall, which influences the bore response;

- the inclusion of diffuse recharge from irrigation in some areas; and

- influences of bank storage and lateral flow from nearby flooded areas.

Limitations in the continental-scale data highlight the need to prioritise the improvement of data sets. The flood inundation data were the driver of the flood recharge system. Improvement in flood inundation data processing is the most critical development for prediction of both location and magnitude of flood recharge using satellite imagery. False positives in the flood data, from saturated soil surfaces, for example, led 
to prediction of recharge in areas where it was not occurring. Similarly, false negative estimations in flood inundation data, due to presence of vegetation and narrow river channels for example, led to flood recharge not being predicted in areas where it did occur. Improving accuracy in the location and spatial extent of flood mapping was most critical for better flood recharge estimates. Improvement in the soil mapping, specific yield and soil hydraulic conductivity estimates was also important. Uncertainties in soil data generally did not affect the spatial distribution of the predicted recharge, but could lead to an under- or over-prediction of the magnitude of recharge in particular locations. More frequent water level readings from a network of bores would assist in increasing confidence in the process during the validation of modelled flood recharge. A network of monitored bores within a catchment where overbank flooding is common and frequent would be a valuable addition to the current data set.

Future research on the application of this method within the AWRA system warrants an uncertainty analysis to determine the sensitivity to input data, and focus on the improvement of input data that maximise the model's accuracy. Crosbie et al. (2013) performed an uncertainty analysis with 10000 realisations of random combinations of four variables on recharge estimates through the beds of losing/disconnected streams at two different point locations. They found that the highest uncertainty was associated with the hydraulic conductivity of the stream bed's clogging layer. In locations where the thickness of the clogging layer was low, both the stream width (area inundated) and stream stage (depth of flooding) were also important, but were eclipsed by the effect of the clogging layer's hydraulic conductivity. An uncertainty analysis at a catchment scale would be useful to indicate the effects of the spatial variability of soil and flood mapping information on the total volume of recharge.

\section{Summary and conclusions}

The volume of groundwater recharge from overbank flooding was modelled for seven Australian catchments to demonstrate the inclusion of OFR calculations into a continentalscale water balance model. Flood recharge was predicted in four of the seven catchments, although unexplained recharge from the satellite imagery input data was also found in the catchments modelled. Validation of the OFR results was undertaken in three of the catchments using point-scale recharge estimated from bore hydrograph responses. This showed a similar spatial distribution of flood recharge, but the OFR method generally under-predicted the volume of recharge. There were no significant relationships between modelled OFR and bore response found at a point scale. Comparison of histograms showed similar distributions of recharge in flooded and non-flooded areas. A more detailed analysis of the Loddon catchment comparing OFR with point-scale recharge modelling under different soil, vegeta- tion, irrigation and flooding conditions showed spatially similar, although lower recharge results from the OFR modelling. This was confirmed with a comparison of OFR at a catchment scale with the change in groundwater storage for the modelled period.

The analysis gave increased confidence that the OFR results at the catchment scale for three of the catchments studied, particularly the spatial nature of the flood recharge, were a reasonable approximation of this process. The nature of the continental-scale data used in the analysis gave low confidence in the applicability of this process at a subcatchment scale. With finer-scale information on flood inundation, and in particular surface clogging layer's hydraulic conductivity and specific yield from soil mapping, it may be possible to apply the OFR equations to smaller-scale field sites. Generally, the methodology of applying the soil's and aquifer's physical limitations to a potential infiltration rate has been valuable (Doble et al., 2012); and could be considered for further application into other areas of surface watergroundwater interactions, including river bed leakage.

The volume of OFR for the Loddon catchment in Victoria, Australia, was found to be at least $4 \%$ of the total volume of recharge to the catchment (including non-flooded areas) and $15 \%$ of the riparian recharge for the period of modelling. This is not an insignificant volume of recharge and it is worthwhile pursuing the development of this process within continental water balance models, particularly if the model is used for the estimation of groundwater sustainable yields or is highly allocated. The methodology is far less computationally intensive than alternative physical process models. The accuracy of the predictions are likely to improve with developments in the production of the soil's hydraulic property data and flood inundation information derived from satellite imagery or other sources such as elevation-based flood inundation calculations.

Acknowledgements. This work is part of the water information research and development alliance between CSIRO's Water for a Healthy Country Flagship and the Bureau of Meteorology. The authors wish to thank the Department of Environment and Primary Industries (DEPI), Victoria, and the Department of Natural Resources and Mines (DNRM), Queensland, for their assistance with providing groundwater bore data. Assistance with flood inundation data was provided by Juan Pablo Guerschman and Peter Thew of CSIRO. Interpolation of water tables in the Loddon catchment was undertaken by Elisabetta Carrara and John Sharples of the Bureau of Meteorology. The authors wish to thank two anonymous reviewers for feedback that has improved this manuscript.

Edited by: Y. Fan 


\section{References}

Bates, P. D. and De Roo, A. P. J.: A simple raster-based model for flood inundation simulation, J. Hydrol., 236, 54-77, doi:10.1016/S0022-1694(00)00278-X, 2000.

Brunner, P. and Simmons, C. T.: HydroGeoSphere: A Fully Integrated, Physically Based Hydrological Model, Ground Water, 50, 170-176, doi:10.1111/j.1745-6584.2011.00882.x, 2011.

Brunner, P., Cook, P. G., and Simmons, C. T.: Hydrogeologic controls on disconnection between surface water and groundwater, Water Resour. Res., 45, doi:10.1029/2008WR006953, 2009.

Collis-George, N. and Freebairn, D. M.: A laboratory and field study of border check irrigation, Aust. J. Soil Res., 17, 75-87, doi:10.1071/SR9790075, 1979.

Cook, F. J., Knight, J. H., Doble, R. C., and Raine, S. R.: An improved solution for the infiltration advance problem in irrigation hydraulics, Irrig. Sci., 31, 1113-1123, doi:10.1007/s00271-0120392-7, 2013.

Coram, J. E., Dyson, P. R., Houlder, P. A., and Evans, W. R.: Australian groundwater flow systems contributing to dryland salinity. Project Report for the National Land and Water Resources Audit, Bureau of Rural Sciences, Canberra, 2000.

Crosbie, R. S., Binning, P., and Kalma, J. D.: A time series approach to inferring groundwater recharge using the water table fluctuation method, Water Resour. Res., 41, W01008, doi:10.1029/2004WR003077, 2005.

Crosbie, R. S., McCallum, J. L., Walker, G. R., and Chiew, F. H. S.: Modelling the climate change impact on groundwater recharge in the Murray-Darling Basin, Hydrogeol. J., 18, 1639-1656, 2010.

Crosbie, R. S., Peeters, L., Doble, R. C., Joehnk, K., Carrara, E., Daamen, C. C., and Frost, A. J.: AWRA-G: A groundwater component for a continental scale land surface model, MODSIM2011, 19th International Congress on Modelling and Simulation, Perth, Australia, 4015-4021, 2011.

Crosbie, R. S., Taylor, A. R., Davis, A. C., Lamontagne, S., and Munday, T.: Evaluation of infiltration from losing-disconnected rivers using a geophysical characterisation of the riverbed and a simplified infiltration model, J. Hydrol., 508, 102-113, doi:10.1016/j.jhydrol.2013.07.045, 2014.

Dahan, O., Tatarsky, B., Enzel, Y., Kulls, C., Seely, M., and Benito, G.: Dynamics of Flood Water Infiltration and Ground Water Recharge in Hyperarid Desert, Ground Water, 46, 450-461, 2008.

Dellepiane, S. G. and Angiati, E.: A New Method for Cross-Normalization and Multitemporal Visualization of SAR Images for the Detection of Flooded Areas, Geoscience and Remote Sensing, IEEE Trans., 50, 2765-2779, doi:10.1109/tgrs.2011.2174999, 2012.

Doble, R. C., Crosbie, R. S., and Smerdon, B. D.: Aquifer recharge from overbank floods, Conceptual and Modelling Studies of Integrated Groundwater, Surface Water and Ecological Systems (Proceedings of Symposium H01 held during IUGG2011), Melbourne, Australia, 2011.

Doble, R. C., Crosbie, R. S., Smerdon, B. D., Peeters, L., and Cook, F. J.: Groundwater recharge from overbank floods, Water Resour. Res., 48, W09522, doi:10.1029/2011wr011441, 2012.

DSE, and DPI: Farm water use efficiency technical reference booklet, Department of Sustainability and Environment and Department of Primary Industries, Victoria, 2004.
Frost, A. J., Bacon, D., Boxall, S., Srikanthan, R., Grant, I. F., Van Dijk, A. I. J. M., Renzullo, L. J., Stenson, M. P., Daamen, C. C., Carrara, E., Barratt, D., Theiveyanathan, T., and Henderson, B. L.: Australian water balance assessment: operational challenges, WIRADA (2012) Water Information Research and Development Alliance: Science Symposium Proceedings, Melbourne, 1-5 August 2011, 2011.

Gouweleeuw, B., Ticehurst, C. J., Gallant, J., Lerat, J., Thew, P., and Minchin, S.: Condamine-Balonne Project: Flood extent and volume estimation. Report prepared for the National Water Commission, CSIRO Water for a Healthy Country, 2011.

Guerschman, J. P., Byrne, G., Ticehurst, C., Gouweleeuw, B., Dyce, P., and Van Dijk, A. I. J. M.: Remote sensing of the dynamics of floods and water bodies in Australia: spatial and temporal scale issues for different applications In AGU 2010 The Meeting of the Americas, 8-13 August 2010, 2010.

Guerschman, J. P., Warren, G., Byrne, G., Lymburner, L., Mueller, N., and Van Dijk, A. I.: MODIS-based standing water detection for flood and large reservoir mapping: algorithm development and applications for the Australian continent, CSIRO, 2011.

Healy, R. and Cook, P.: Using groundwater levels to estimate recharge, Hydrogeol. J., 10, 91-109, doi:10.1007/s10040-0010178-0, 2002.

Hostache, R., Matgen, P., Schumann, G., Puech, C., Hoffmann, L., and Pfister, L.: Water Level Estimation and Reduction of Hydraulic Model Calibration Uncertainties Using Satellite SAR Images of Floods, Geoscience and Remote Sensing, IEEE Trans., 47, 431-441, doi:10.1109/tgrs.2008.2008718, 2009.

Isbell, R. F.: The Australian Soil Classification, CSIRO Publishing, Collingwood, 2002.

Jeffrey, S. J., Carter, J. O., Moodie, K. B., and Beswick, A. R.: Using spatial interpolation to construct a comprehensive archive of Australian climate data, Environ. Modell. Softw., 16, 309-330, 2001.

Joehnk, K. D., Crosbie, R. S., Peeters, L., and Doble, R. C.: AWRA$\mathrm{G}$ : groundwater component of AWRA, CSIRO: Water for a Healthy Country National Research Flagship, Australia, 2012.

Johnston, R. M., Barry, S. J., Bleys, E., Bui, E. N., Moran, C. J., Simon, D. A. P., Carlile, P., McKenzie, N. J., Henderson, B. L., Chapman, G., Imhoff, M., Maschmedt, D., Howe, D., Grose, C., Schoknecht, N., Powell, B., and Grundy, M.: ASRIS: the database, Soil Res., 41, 1021-1036, doi:10.1071/SR02033, 2003.

Jolly, I. D.: The effects of river management on the hydrology and hydroecology of arid and semi-arid floodplains, in: Floodplain Processes, edited by: Anderson, M. G., Walling, D. E., and Bates, P. D., John Wiley \& Sons Ltd., Chichester, New York, 577-609, 1996.

Jolly, I. D., Walker, G. R., and Narayan, K. A.: Floodwater recharge processes in the Chowilla Anabranch system, Aust. J. Soil Res., 32, 417-435, 1994.

Jolly, I. D., Narayan, K. A., Armstrong, D., and Walker, G. R.: The impact of flooding on modelling salt transport processes to streams, Environ. Modell. Softw., 13, 87-104, 1998.

Knight, J.: An Improved Solution for the lnfiltration-advance Problem in Irrigation Hydraulics, 7th Australasian Conference on Hydraulics and Fluid Mechanics 1980: Preprints of Papers, Barton, A.C.T., Australasian Conference on Hydraulics and Fluid Mechanics (7th: 1980: Brisbane, Qld.), 258-260, 1980. 
Kollet, S. J. and Maxwell, R. M.: Capturing the influence of groundwater dynamics on land surface processes using an integrated, distributed watershed model, Water Resour. Res., 44, W02402, doi:10.1029/2007wr006004, 2008.

Leighton, B., Lerat, J., and Stenson, M.: AWRA and Source Integration: Purpose, Requirements and Data Exchanges, CSIRO: Water for a Healthy Country National Research Flagship, 2011.

Lemieux, J. M., Sudicky, E. A., Peltier, W. R., and Tarasov, L.: Dynamics of groundwater recharge and seepage over the Canadian landscape during the Wisconsinian glaciation, J. Geophys. Res., 113, F01011, doi:10.1029/2007jf000838, 2008.

Lewis, M. R. and Milne, W. E.: Analysis of border irrigation, Agr. Eng., 19, 267-272, 1938.

Lindström, G.: Development and testing of the HYPE (Hydrological Predictions for the Environment) water quality model for different spatial scales, Nord. Hydrol., 41, 295-319, doi:10.2166/nh.2010.007, 2010.

Liu, S. F., Raymond, O. L., Stewart, A. J., Sweet, I. P., Duggan, M. B., Charlick, C., Phillips, D., and Retter, A. J.: Surface geology of Australia 1:1,000,000 scale, Northern Territory [Digital Dataset], The Commonwealth of Australia, Geoscience Australia, available at: http://www.ga.gov.au, Canberra, 2006.

Long, D. and Singh, V. P.: Integration of the GG model with SEBAL to produce time series of evapotranspiration of high spatial resolution at watershed scales, J. Geophys. Res.-Atmos., 115, D21128, doi:10.1029/2010jd014092, 2010.

Macumber, P. G.: Interactions between groundwater and surface systems in northern Victoria, PhD Thesis, University of Melbourne, Melbourne, Vic., p. 506, 1983.

Martinis, S., Twele, A., and Voigt, S.: Unsupervised Extraction of Flood-Induced Backscatter Changes in SAR Data Using Markov Image Modeling on Irregular Graphs, Geoscience and Remote Sensing, IEEE Trans., 49, 251-263, doi:10.1109/tgrs.2010.2052816, 2011.

Maxwell, R. M. and Miller, N. L.: Development of a Coupled Land Surface and Groundwater Model, J. Hydrometeorol., 6, 233-247, doi:10.1175/jhm422.1, 2005.

Overton, I. C.: Modelling floodplain inundation on a regulated river: integrating GIS, remote sensing and hydrological models, River Res. Applic., 21, 991-1001, 2005.

Peeters, L. J. M., Crosbie, R. S., Doble, R. C., and Van Dijk, A. I. J. M.: Conceptual evaluation of continental landsurface model behaviour, Environ. Modell. Softw., 43, 49-59, doi:10.1016/j.envsoft.2013.01.007, 2013.

Peterson, T. J., Cheng, X., Western, A. W., Siriwardena, L., and Wealands, W. R.: Novel indicator geostatistics for water table mapping that incorporate elevation, land use, stream network and physical constraints to provide probabilistic estimation of heads and fluxes, MODSIM2011, 19th International Congress on Modelling and Simulation, Perth, Australia, 4015-4021, 2011.

Philip, J. R.: Absorption and infiltration in two- and three- dimensional systems, Water in the Unsaturated Zone, Paris, 1966.

Philip, J. R.: Theory of infiltration, Adv. Hydrosci., 5, 215-296, 1969.

Philip, J. R. and Farrell, D. A.: General Solution of the InfiltrationAdvance Problem in Irrigation Hydraulics, J. Geophys. Res., 69, 621-631, doi:10.1029/JZ069i004p00621, 1964.
Raymond, O. L., Liu, S. F., Kilgour, P., Retter, A. J., and Connolly, D. P.: Surface geology of Australia 1:1,000,000 scale, Victoria, 3rd Edn. [Digital Dataset], Geoscience Australia, available at: http://www.ga.gov.au, Canberra, 2007a.

Raymond, O. L., Liu, S. F., Kilgour, P., Retter, A. J., Stewart, A. J., and Stewart, G.: Surface geology of Australia 1:1,000,000 scale, New South Wales, 2nd Edn. [Digital Dataset], Geoscience Australia, available at: http://www.ga.gov.au, Canberra, 2007b.

Reager, J. T. and Famiglietti, J. S.: Characteristic mega-basin water storage behavior using GRACE, Water Resour. Res., 49, 3314 3329, doi:10.1002/wrcr.20264, 2013.

Shentsis, I. and Rosenthal, E.: Recharge of aquifers by flood events in an arid region, Hydrol. Process., 17, 695-712, 2003.

Singh, V. and Woolhiser, D.: Mathematical Modeling of Watershed Hydrology, J. Hydrol. Eng, 7, 270-292, doi:10.1061/(ASCE)1084-0699(2002)7:4(270), 2002.

Stewart, A. J., Sweet, I. P., Needham, R. S., Raymond, O. L., Whitaker, A. J., Liu, S. F., Phillips, D., Retter, A. J., Connolly, D. P., and Stewart, G.: Surface geology of Australia 1:1,000,000 scale, Western Australia [Digital Dataset], Geoscience Australia, http://www.ga.gov.au, Canberra, 2008.

Strömqvist, J., Arheimer, B., Dahné, J., Chantal, D., and Göran, L.: Water and nutrient predictions in ungauged basins: set-up and evaluation of a model at the national scale, Hydrol/ Sci/ J/, 57, 229-247, doi:10.1080/02626667.2011.637497, 2012.

Therrien, R., McLaren, R. G., Sudicky, E. A., and Panday, S. M.: Hydrogeosphere - a three-dimensional numerical model describing fully-integrated subsurface and surface flow and solute transport, Groundwater Simul. Group, Waterloo, Ont., Canada, Université Laval, University of Waterloo, 275 pp., 2006.

Ticehurst, C. J., Dyce, P., and Guerschman, J. P.: Using passive microwave and optical remote sensing to monitor flood inundation in support of hydrologic modelling, 18th World MACS/MODSIM Congress, Cairns, Australia, 2009.

Tregoning, P., McClusky, S., van Dijk, A. I. J. M., Crosbie, R. S., and Peña-Arancibia, J. L.: Assessment of GRACE satellites for groundwater estimation. Waterlines report, National Water Commission, Canberra, Australia, 2012.

van Dijk, A. I. J. M.: The Australian Water Resources Assessment System. Technical Report 3. Landscape Model (version 0.5) Technical Description, CSIRO: Water for a Healthy Country National Research Flagship, available at: http://www.clw.csiro.au/publications/waterforahealthycountry/ 2010/wfhc-aus-water-resources-assessment-system.pdf, 2010.

van Dijk, A. I. J. M. and Renzullo, L. J.: Water resource monitoring systems and the role of satellite observations, Hydrol. Earth Syst. Sci., 15, 39-55, doi:10.5194/hess-15-39-2011, 2011.

Van Dijk, A. I. J. M., Bacon, D., Barratt, D., Crosbie, R. S., Daamen, C. C., Fitch, P., Frost, A. J., Guerschman, J. P., Henderson, B. L., King, E. A., McVicar, T. R., Renzullo, L. J., Stenson, M. P., and Viney, N. R.: Design and development of the Australian Water Resources Assessment system, WIRADA (2012) Water Information Research and Development Alliance: Science Symposium Proceedings, Melbourne, 1-5 August 2011, 2011. 
Vaze, J., Viney, N., Stenson, M., Renzullo, L., Dijk, A. V., Dutta, D., Crosbie, R., Lerat, J., Penton, D., Vleeshouwer, J., Peeters, L., Teng, J., Kim, S., Hughes, J., Dawes, W., Zhang, Y., Leighton, B., Perraud, J.-M., Joehnk, K., A.Yang, Wang, B., Frost, A., Elmahdi, A., Smith, A., and Daamen, C.: The Australian Water Resource Assessment Modelling System (AWRA), MODSIM 2013, Adapting to change: the multiple roles of modelling, 20th International Congress on Modelling and Simulation (MODSIM2013), Adelaide, Australia, 1-6 December 2013, available at: www.mssanz.org.au/modsim2013, 2013.

Viney, N. R., Vaze, J., Wang, B., Zhang, Y., Yang, A., Vleeshouwer, J., Ramchurn, A., and Frost, A.: Comparison of prediction performance of AWRA-L with other models, CSIRO Water for a Healthy Country Flagship, Australia, 2013.

Wada, Y.: Global depletion of groundwater resources, Geophys. Res. Lett., 37, L20402, doi:10.1029/2010GL044571, 2010.

Wada, Y., van Beek, L. P. H., and Bierkens, M. F. P.: Nonsustainable groundwater sustaining irrigation: A global assessment, Water Resour. Res., 48, W00L06, doi:10.1029/2011wr010562, 2012.
Westerhoff, R. S., Kleuskens, M. P. H., Winsemius, H. C., Huizinga, H. J., Brakenridge, G. R., and Bishop, C.: Automated global water mapping based on wide-swath orbital synthetic-aperture radar, Hydrol. Earth Syst. Sci., 17, 651-663, doi:10.5194/hess17-651-2013, 2013.

Whitaker, A. J., Champion, D. C., Sweet, I. P., Kilgour, P., and Connolly, D. P.: Surface geology of Australia 1:1,000,000 scale, Queensland, 2nd Edn. [Digital Dataset] Geoscience Australia, available at: http://www.ga.gov.au, Canberra, 2007.

Whitaker, A. J., Glanville, H. D., English, P. M., Stewart, A. J., Retter, A. J., Connolly, D. P., Stewart, G. A., and Fisher, C. L.: Surface geology of Australia 1:1,000,000 scale, South Australia, 1st Edn. [Digital Dataset] Geoscience Australia, available at: http://www.ga.gov.au, Canberra, 2008.

Zhang, L. and Dawes, W.: WAVES - An integrated energy and water balance model, CSIRO Land and WaterTechnical Report No. 31/98, 218, 1998. 


\section{Appendix A}

Table A1. Data used to populate the overbank flood recharge equations in AWRA-G.

\begin{tabular}{|c|c|}
\hline Parameter & Description \\
\hline$d_{\mathrm{gw}}$ & $\begin{array}{l}\text { Depth to groundwater calculated from the } 9 \mathrm{~s} \text { land } \\
\text { surface DEM for the } 0.05^{\circ} \text { cell minus the elevation } \\
\text { of the water table, wt. }\end{array}$ \\
\hline wt & $\begin{array}{l}\text { Initial water table map derived from the minimum } \\
\text { value of the } 9 \mathrm{~s} \text { land surface DEM within each } \\
0.05^{\circ} \text { model cell. }\end{array}$ \\
\hline$S_{\mathrm{y}}$ & $\begin{array}{l}\text { Aquifer specific yield derived from a simplified } \\
\text { surface geology map of Australia (Raymond et } \\
\text { al., 2007a), with a range of } 0.06-0.3 \text { (Joehnk et } \\
\text { al., 2012) and for the Loddon, Campaspe, Mur- } \\
\text { rumbidgee and Lachlan catchments, a more de- } \\
\text { tailed specific yield map ranging from } 0.03 \text { to 0.2. }\end{array}$ \\
\hline$x_{w}$ & $\begin{array}{l}\text { The lateral extent of flooding calculated from the } \\
\text { width of the model cell multiplied by the likeli- } \\
\text { hood of open water being present within the cell, } \\
\text { derived from MODIS satellite imagery (Ticehurst } \\
\text { et al., 2009). }\end{array}$ \\
\hline$K_{\mathrm{c}}$ & $\begin{array}{l}\text { Hydraulic conductivity of the clogging layer cal- } \\
\text { culated from a weighted mean of the hydraulic } \\
\text { conductivity of the two surface soils presented in } \\
\text { the Australian Soil Resource Information System } \\
\text { (ASRIS) database (Johnston et al., 2003) }{ }^{1} \text {. }\end{array}$ \\
\hline$h_{w}$ & $\begin{array}{l}\text { Depth of inundation from MODIS satellite im- } \\
\text { agery (Ticehurst et al., 2009). }\end{array}$ \\
\hline$d_{\mathrm{c}}$ & $\begin{array}{l}\text { Thickness of the clogging layer calculated from } \\
\text { the sum of the thicknesses of the two surface soils } \\
\text { presented in the ASRIS database* (Johnston et al., } \\
\text { 2003). }\end{array}$ \\
\hline$t_{w}$ & $\begin{array}{l}\text { The duration of inundation, assumed to be one } \\
\text { model time step, or } 1 \text { day. }\end{array}$ \\
\hline$K_{\mathrm{aq}}$ & $\begin{array}{l}\text { The hydraulic conductivity of the aquifer de- } \\
\text { rived from a simplified surface geology map of } \\
\text { Australia (Raymond et al., 2007a), described in } \\
\text { Joehnk et al. (2012) }\end{array}$ \\
\hline$d_{\mathrm{aq}}$ & $\begin{array}{l}\text { The thickness of the aquifer derived from ground- } \\
\text { water flow system maps of Australia (Coram et al., } \\
\text { 2000), described in Joehnk et al. (2012) }\end{array}$ \\
\hline
\end{tabular}

* Australian Soil Resource Information System (http://www.asris.csiro.au/). 